\title{
Prevalence, characteristics and correlates of enteric pathogenic protozoa in drinking water sources in Molyko and Bomaka, Cameroon: a cross-sectional study
}

\author{
Fuh Anold Nsoh¹, Buh Amos Wung ${ }^{1,2^{*}}$, Julius Atashili ${ }^{1,2}$, Pokam Thumamo Benjamin ${ }^{1}$, Eba Marvlyn ${ }^{1}$,
} Keumami Katte Ivo ${ }^{1,2}$ and Assob Jules Clément Nguedia ${ }^{1}$

\begin{abstract}
Background: Access to potable water remains a major challenge particularly in resource-limited settings. Although the potential contaminants of water are varied, enteric pathogenic protozoa are known to cause waterborne diseases greatly. This study aimed at investigating the prevalence, characteristics and correlates of enteric pathogenic protozoa in drinking water sources in Buea, Cameroon.

Methods: A cross-sectional study was conducted using 155 water samples collected from various drinking sources (boreholes, springs, taps and wells). Each sample was subjected to physicochemical examinations ( $\mathrm{pH}$, turbidity, odour and sliminess) and parasitological analysis (wet mount, modified Ziehl-Neelsen stain) to determine the presence of enteric pathogenic protozoa. A data collection tool was used to note characteristics of collected samples and the data was analysed using EPI-INFO Version 3.5.3.

Results: The overall prevalence of enteric pathogenic protozoa in water sources was $62.6 \%$. Eight species of enteric protozoa were observed with Cryptosporidium parvum being the most predominant (45.8\%). Spring water was the most contaminated source with enteric protozoa (85.7\%) while pipe borne water had all eight species of protozoa identified. A pH of 6 was the only significant factor associated with the prevalence of these pathogens in water sources.

Conclusion: The prevalence of enteric protozoa in water sources in Molyko and Bomaka is high, spring water is the most contaminated water source and Cryptosporidium parvum is the most common protozoa contaminating water. A water $\mathrm{pH}$ of 6 is associated to the prevalence of protozoa. Community members need to be educated to treat water before drinking to avoid infection by enteric protozoa in water and further studies with larger samples of water need to be conducted to find other correlates of the presence of protozoa in water.
\end{abstract}

Keywords: Enteric pathogenic protozoa, Drinking water, Prevalence, Buea, Cameroon

\section{Background}

Water covers almost $70 \%$ of the earth's surface but most water sources are saline with the drinkable type (fresh water) constituting only $2.5 \%$ of the earth's water [1]. Access to drinking water is not only important for health but also for sustainable development, food production and poverty reduction [2]. Despite its importance, access to safe drinking water remains a challenge worldwide. In

\footnotetext{
* Correspondence: bamosw@yahoo.fr

${ }^{1}$ Faculty of Health Sciences, University of Buea, P.O. Box 63, Buea, Cameroon ${ }^{2}$ Department of Public Health and Hygiene, Faculty of Health Sciences, University of Buea, P.O. Box 63, Buea, Cameroon
}

2010, reports showed that safe drinking water remained inaccessible to over 1.1 billion people in the world with about 400 deaths of children below the age of five arising every hour due to biological contamination of water [3].

Contaminants of water can either be microorganisms (bacteria, protozoa, helminths and viruses) or chemicals [4]. Microorganisms are often found in water as a result of sewage discharges (containing faecal matter), leaking septic tanks and runoffs from animal feedlots [5]. Chemical contaminants on the other hand, are usually considered a lower priority contaminant since their adverse health 
effects are generally associated with long term exposure whereas the effects of microbial contaminants are usually immediate [6].

Enteric protozoa are a major waterborne pathogen in developing countries causing diarrhoeal illnesses in humans, with some causing a severe debilitating illness that can shorten the lifespan of an immune compromised individual [7]. Bacterial contamination, however, contributes to the largest share of the diarrhoea disease burden associated with unsafe drinking water with children less than 5 years of age being very vulnerable [8].

The types of enteric protozoa that can be found in water are diverse. In developing settings such as sub-Saharan Africa and Asia, the common enteric pathogenic protozoa that can be found in water include Entamoeba species (spp), Cryptosporidium spp, Giardia intestinalis, Microsporidia species and Cyclospora cayetanensis $[9,10]$. Other species such as Blastocystis spp and Dientamoeba fragilis are usually isolated in developed countries [9].

In sub-Saharan Africa, the transmission of these enteric parasites in water is favoured by socio-economic factors such as poor hygiene, lack of safe water and sanitation facilities. Low socio-economic status is known to play a pivotal role in susceptibility to infection [11]. Secondly, most of the enteric parasites have the ability to complete their life-cycles within a single host that excretes large numbers of infective transmissible stages (such as Giardia cysts and Cryptosporidium oocysts) in faeces. Also, zoonotic transmission of enteric protozoa enhances both the reservoir of infection and environmental contamination, thereby increasing the likelihood of waterborne transmission [12].

Some studies in Africa have shown the presence of protozoa in water sources. In Nigeria for example, a study [13] on parasites in domestic water sources reported a prevalence of enteric pathogenic protozoa of $42.4 \%$ while in Zimbabwe, a prevalence of enteric pathogenic protozoa of $36.6 \%$ was reported [14]. In Ghana, a prevalence of up to $77.8 \%$ of enteric protozoa in water samples was reported [10].

However, in Cameroon, no study has been carried out on the prevalence of enteric pathogenic protozoa in drinking water sources. Instead, studies on these pathogens have used stool samples of patients attending hospitals [15] and food vendors [16]. The objective of this study therefore was to provide data on the prevalence, different species of protozoa and the factors associated with the prevalence of these species in drinking water sources in the Molyko and Bomaka communities in Buea.

\section{Methods}

\section{Study design and setting}

A cross-sectional, descriptive and analytic study was conducted on water samples collected in Molyko (an urban community) and Bomaka (a semi-urban community) both found in Buea, Cameroon.

Briefly, Buea is a town and capital of the South-West Region. It covers a surface area of about $870 \mathrm{~km}^{2}$, with a population of 200,000 [17]. The town is located at the base of Mount Cameroon and has 85 villages. Buea is renowned for its high-quality groundwater percolating into the volcanic sub-strata of the mountain and surfacing as natural springs in various locations towards the middle and lower regions of the town. These 'traditional' water sources supplement public supply, and are heavily used by the town's inhabitants for activities ranging from drinking, to construction, and the washing of vehicles. Inhabitants of Molyko predominantly use pipe borne water either from the national water supplier (CAMWATER) or community water supplies. Very few boreholes are found in this area. Bomaka on the other hand does not have national water supplies and its dwellers use boreholes, springs, wells or community pipe-borne water supplies.

\section{Study sample and sampling}

The study samples were drinking water samples collected from taps, wells, boreholes and springs from June 2014 to August 2014. The sample size was determined using a formula for estimating population proportions for a crosssectional study [18]. We assumed the prevalence of enteric pathogenic protozoa in drinking water sources to be $42.4 \%$ as reported in a study in Nigeria [13], a $95 \%$ confidence level and an error margin of $7 \%$. This gave a sample size of 192. However, 155 samples were collected because most quarters in Bomaka shared a common drinking source.

Convenience sampling was done by dividing Molyko and Bomaka respectively into 14 and 7 quarters. To estimate the number of samples to be collected from each quarter, the 155 sample size was divided by the 21 quarters in the study. This gave seven water samples per quarter.

Table 1 Distribution of 155 water samples based on place of collection and water suppliers/sources

\begin{tabular}{|c|c|c|c|}
\hline & \multicolumn{2}{|c|}{ Place of collection } & \multirow[t]{2}{*}{ Total (\%) } \\
\hline & Molyko & Bomaka & \\
\hline \multicolumn{4}{|l|}{ Water suppliers } \\
\hline National (\%) & $79(68.1)$ & $0(0.0)$ & $79(51.0)$ \\
\hline Community (\%) & $28(24.1)$ & $21(53.8)$ & 49 (31.6) \\
\hline Individual (\%) & $9(7.8)$ & $18(46.2)$ & $27(17.4)$ \\
\hline \multicolumn{4}{|l|}{ Water sources } \\
\hline Borehole (\%) & $14(12.1)$ & $6(15.4)$ & $20(12.9)$ \\
\hline Spring (\%) & $2(1.7)$ & $5(12.8)$ & $7(4.5)$ \\
\hline Tap (\%) & $100(86.2)$ & $20(51.3)$ & $120(77.4)$ \\
\hline Well (\%) & $0(0.0)$ & $8(20.5)$ & $8(5.2)$ \\
\hline
\end{tabular}

$\%$ percentage 
Table 2 Characteristics of water sources of the 155 collected samples

\begin{tabular}{lll}
\hline Characteristics of water source & Frequency $(\mathrm{N})$ & Percentage (\%) \\
\hline Location of the water source & & \\
Open (outdoor) & 104 & 67.1 \\
Closed (indoor) & 51 & 32.9
\end{tabular}

Lid on water source

Present
$N A^{*}$
Height above the ground
$\leq 1$ metre
$>1$ metre
$N A^{*}$

Pipes exposed

\section{Not exposed}

Exposed

NA

10

Distance from toilet or pit latrine

$\begin{array}{ll}0-1 \mathrm{~m} & 3 \\ 2-10 \mathrm{~m} & 9 \\ >10 \mathrm{~m} & 143\end{array}$

Distance from septic tanks

$\begin{array}{ll}0-1 \mathrm{~m} & 1 \\ 2-10 \mathrm{~m} & 26 \\ >10 \mathrm{~m} & 128\end{array}$

Distance from farms

$\begin{array}{ll}0-1 \mathrm{~m} & 17 \\ 2-10 \mathrm{~m} & 22 \\ >10 \mathrm{~m} & 116\end{array}$

Animals around source

$\begin{array}{lll}0-1 \mathrm{~m} & 2 & 1.3 \\ 2-10 \mathrm{~m} & 1 & 0.6 \\ >10 \mathrm{~m} & 155 & 98.1\end{array}$

Existence of source

$\begin{array}{ll}0-5 \text { years } & 70 \\ 6-10 \text { years } & 37 \\ >10 \text { years } & 48\end{array}$

Mud around source

Absent

Present

Covered by cement

Absent
Present
Stagnant water

Table 2 Characteristics of water sources of the 155 collected samples (Continued)

\begin{tabular}{|c|c|c|}
\hline \multicolumn{3}{|l|}{ Enter water with feet } \\
\hline No & 2 & 1.3 \\
\hline Yes & 5 & 3.2 \\
\hline$N A^{*}$ & 148 & 95.5 \\
\hline \multicolumn{3}{|l|}{ Cleaning frequency } \\
\hline Never or rarely & 19 & 12.3 \\
\hline Weekly & 80 & 51.6 \\
\hline Monthly & 51 & 32.9 \\
\hline Yearly & 5 & 3.2 \\
\hline \multicolumn{3}{|l|}{$\mathrm{pH}$} \\
\hline 6 & 30 & 19.4 \\
\hline 7 & 125 & 80.6 \\
\hline \multicolumn{3}{|l|}{ Turbidity } \\
\hline Clear & 141 & 91.0 \\
\hline Cloudy & 2 & 1.3 \\
\hline Brownish & 2 & 1.3 \\
\hline Contain particles & 10 & 6.5 \\
\hline \multicolumn{3}{|l|}{ Odour } \\
\hline No & 145 & 93.5 \\
\hline Yes & 10 & 6.5 \\
\hline \multicolumn{3}{|l|}{ Sliminess } \\
\hline Not slimy & 145 & 93.5 \\
\hline Slimy & 10 & 6.5 \\
\hline
\end{tabular}

$N$ frequency, $N A^{*}$ not applicable to the given characteristic, \% percentage

\section{Data and sample collection}

Data collection was done by one of the investigators using forms to record information on some characteristics which could influence prevalence of protozoa in water such as the water supplier (national, community, individual), source of water (river, stream, spring, well, borehole, tap), location of water source (open air or in a closed environment), exposure of pipes to the surface, presence or absence of a lid on the water source and distance of the water source from animal contact, toilets, pit latrines, septic tanks and farms. We also collected information on how often these water sources were cleaned and observed the physical environment that surrounded these water sources.

Clean bottles were used to collect water samples at consumption points for physicochemical and parasitological analysis. All samples collected were labelled with date of collection, identification number and site of collection. The information collected was then registered in a sampling and parasitological analysis form and transported to the Faculty of Health Sciences' Teaching Laboratory at the University of Buea for analysis. 


\section{Physicochemical and parasitological analysis/ measurements}

Physicochemical analysis of the water samples involved the measurement of the $\mathrm{pH}$, turbidity, odour and sliminess. Measurement of $\mathrm{pH}$ was done using Whatman ${ }^{\text {тм }}$ 2600-100A pH test paper. Turbidity, odour and sliminess were evaluated using sense organ perceptions by the investigator during collection of the water sample at its source following recommended methods [14].

With regards to parasitological analysis, each collected sample was shaken and the cap of the water bottle carefully removed avoiding touching the opening with bare hands. The bottle contents were dispensed into falcon test tubes and centrifuged at 2000 rotations per minute (rpm) for 5 minutes. Then, the contents of each of these test tubes were pooled together after the supernatant fluid had been discarded. The combined sediment were re-centrifuged under the same conditions as above and the supernatant fluid was again discarded for the sediments to be examined microscopically as recommended by Kwakye-Nuako and colleagues [10]. Direct wet/iodine preparation for identification of cysts was done using the method described by the WHO [19] while Modified Ziehl-Neelsen technique was done to detect the presence of other cysts and coccidian oocysts as documented by Kwakye-Nuako and colleagues [10].

\section{Data management and statistical analysis}

All data from the data collection form were keyed into an Epi Info database (WHO/CDC Atlanta, USA) and analysed using Epi Info version 3.5.3, Statistical package for Social Sciences (SPSS) Statistics 20 and Microsoft excel 2007. Water samples were described using frequencies and percentages of the water sources from which they were collected and the species and number of water samples with enteric pathogenic protozoa.

The prevalence of enteric pathogenic protozoa in the drinking water sources was obtained by computing the ratio of the number of water samples containing protozoa and the total number of water samples analysed (expressed as a percentage).

To characterise the pathogens in terms of species, the ratio of the number of water samples with a pathogen of interest and the total number of samples which contain enteric pathogenic protozoa (expressed as a percentage) was calculated.

To determine the factors associated with the presence of enteric pathogenic protozoa in water sources, bivariate

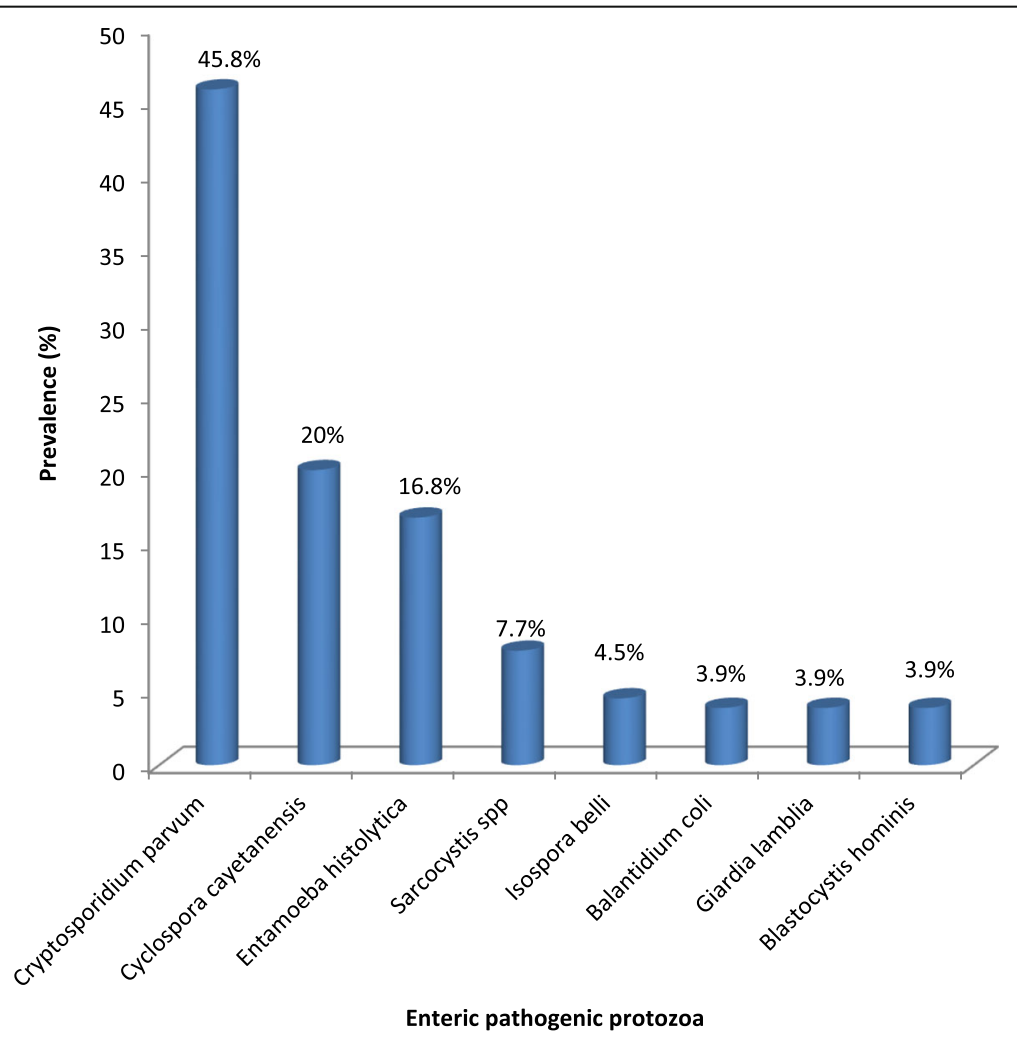

Fig. 1 Prevalence of individual enteric pathogenic protozoa observed in water samples. The data in this figure presents the prevalence of the protozoa that were observed in the water samples (Cryptosporidium parvum (45.8\%), Cyclospora cayetanensis (20 \%), Entamoeba hystolytica (16.8\%), Sarcocystis spp (7.7\%), Isospora belli (4.5\%), Balantidium coli (3.9\%), Giardia lamblia (3.9 \%), Blastocystis hominis (3.9\%)) 
Table 3 Rate of contamination of water sources by enteric pathogenic protozoa

\begin{tabular}{llll}
\hline Water source & $\begin{array}{l}\text { Number of samples } \\
\text { collected }\end{array}$ & $\begin{array}{l}\text { Number of positive } \\
\text { samples }\end{array}$ & (\%) \\
\hline Borehole & 20 & 12 & 60.0 \\
Spring water & 7 & 6 & 85.7 \\
Tap water & 120 & 77 & 64.2 \\
Well & 8 & 2 & 25.0 \\
Total & 155 & 97 & 62.6 \\
\hline
\end{tabular}

$\%$ percentage

and multivariate analysis was done. Bivariate analysis was done by considering the prevalence of protozoa as a binary outcome variable and the characteristics of water sources as predictors. Unadjusted odd ratios, $95 \%$ confidence intervals and $\mathrm{p}$-values were computed. All variables with $p$-values $\leq 0.2$ were considered as having a potential association to prevalence of protozoa and were considered for further analysis in a multivariate logistic regression model to check for confounders. The multivariate analysis was done by considering prevalence of protozoa as a binary outcome variable and variables with p-values $\leq 0.2$ in the bivariate analysis as predictors. Adjusted odd ratios, $95 \%$ confidence intervals and p-values were also computed. Any variable that had a p-value $<0.05$ was considered as having a statistically significant association with the prevalence of enteric pathogenic protozoa in water sources.

\section{Results}

\section{Water sources and sample characteristics}

Of the 155 water samples analysed $51 \%$ was collected from the national water supplier source. Most (68.1\%) of the water samples collected in Molyko were from the national water supplier while $53.8 \%$ of the water samples in Bomaka were obtained from the community water supplier source. Overall, $77.4 \%$ of water samples were collected from taps (Table 1).

Most water sources such as boreholes and wells constructed outside homes (67.1\%) were uncovered and $91 \%$ of them were constructed at least one metre above the ground. Over $30 \%$ of pipe borne water sources had pipes exposed to the surface. Most of the sources $(92.3 \%$ and $82.6 \%$ ) were located more than 10 metres away from toilets or pit latrines and septic tanks respectively. Seventy $(45.2 \%)$ of the water sources had existed for at most 5 years and mud surrounded $39.4 \%$ of the water sources even though $51.6 \%$ of the water sources were reported to be cleaned weekly. The predominant $\mathrm{pH}$ of most water sources $(80.6 \%)$ ranged between 6 and 7 (Table 2).

\section{Prevalence and characterisation of enteric pathogenic protozoa}

Of the 155 water samples examined, 97 (62.6\%) harboured enteric pathogenic protozoa. Eight species of enteric pathogenic protozoa were observed with Cryptosporidium parvum oocytes ( $45.8 \%$ ) being the most common (Fig. 1). Water from springs had the highest degree of contamination $(85.7 \%)$ with enteric pathogenic protozoa (Table 3). Most of these spring water sources (71.4 \%) mainly harboured Cryptosporidium parvum. Only tap water harboured all the eight species of enteric pathogenic protozoa observed (Table 4).

\section{Correlates of enteric pathogenic protozoa in water sources}

Tables 5 and 6 presents the correlates of enteric pathogenic protozoa in water sources. In the bivariate analysis, the factors that appeared to have an association with the prevalence of enteric pathogenic protozoa in water sources include having opened water sources when compared to closed ones, having water sources out of homes with no lids when compared to sources that do not need lids, having water sources with exposed pipes when compared to sources with unexposed pipes, having water sources $\leq 10 \mathrm{~m}$ away from septic tanks when compared to sources $>10 \mathrm{~m}$ away from septic tanks, having water sources that have existed for more than 5 years when compared to sources with five or less years of existence, having mud around water sources when compared to sources with no mud surrounding them, having water sources with non-cemented surroundings, having water sources that are rarely/never cleaned when compared to sources that are at least cleaned weekly/monthly, having water sources with a

Table 4 Distribution of enteric pathogenic protozoa in the 4 different water sources

\begin{tabular}{llllllllll}
\hline Water source $(n=155)$ & $\mathrm{CP}(\%)$ & $\mathrm{CC}(\%)$ & $\mathrm{EH}(\%)$ & Sarco $(\%)$ & $\mathrm{IB}(\%)$ & $\mathrm{BC}(\%)$ & $\mathrm{GL}(\%)$ & $\mathrm{BH}(\%)$ & Total *(\%) \\
\hline Boreholes $(n=20)$ & $9(45.0)$ & $8(40.0)$ & $0(0.0)$ & $3(15.0)$ & $1(5.0)$ & $1(5.0)$ & $1(5.0)$ & $2(10)$ & $25(15.3)$ \\
Springs $(n=7)$ & $5(71.4)$ & $0(0.0)$ & $3(42.9)$ & $0(0.0)$ & $1(14.3)$ & $0(0.0)$ & $1(14.3)$ & $0(0.0)$ & $10(6.1)$ \\
Taps $(n=120)$ & $57(47.5)$ & $21(17.5)$ & $21(17.5)$ & $9(7.5)$ & $5(4.2)$ & $5(4.2)$ & $4(3.3)$ & $4(3.3)$ & $126(77.3)$ \\
Wells $(n=8)$ & $0(0.0)$ & $1(12.5)$ & $1(12.5)$ & $0(0.0)$ & $0(0.0)$ & $0(0.0)$ & $0(0.0)$ & $0(0.0)$ & $2(1.2)$ \\
Total** & $71(45.8)$ & $30(19.4)$ & $25(16.1)$ & $12(7.7)$ & $7(4.5)$ & $6(3.9)$ & $6(3.9)$ & $6(3.9)$ & 163 \\
\hline
\end{tabular}

CP Cryptosporidum parvum, CC Cyclospora cayetanensis, EH Entamoeba histolytica, Sarco Sarcocystis spp, IB Isospora belli, BC Balantidium coli, GL Giardia lamblia, $\mathrm{BH}$ Blastocystis hominis, Total* $=$ total number of pathogens identified, Total** $=$ total number of individual species of protozoa in 155 water samples 
Table 5 Correlates of enteric pathogenic protozoa in water sources-bivariate analysis

\begin{tabular}{llllll}
\hline Predictor & $N$ & $\%$ & OR $^{*}$ & $95 \% \mathrm{Cl}$ & $p$-value \\
\hline
\end{tabular}

\begin{tabular}{llllll}
\hline Location of water source & & & & & \\
Closed & 28 & 54.9 & Ref & & \\
Open & 69 & 66.3 & 1.62 & $0.82-3.21$ & 0.16
\end{tabular}

Lid on water source

NA
Yes

$\begin{array}{lllll}87 & 65.1 & \text { Ref } & & \\ 15 & 51.7 & 0.57 & 0.25-1.30 & 0.18\end{array}$

Height above ground level

$\begin{array}{llllll}\leq 1 \mathrm{~m} & 6 & 60.0 & \text { Ref } & & \\ >1 \mathrm{~m} & 88 & 62.4 & 1.11 & 0.30-4.10 & 0.88 \\ \mathrm{NA} & 3 & 75.0 & 2.00 & 0.15-26.72 & 0.60\end{array}$

Pipes exposed

Not exposed
Exposed
NA

Distance from toilet

$\leq 1 \mathrm{~m}$
$2-10 \mathrm{~m}$
$>10 \mathrm{~m}$

Distance from septic tank

$$
\begin{aligned}
& >10 \mathrm{~m} \\
& \leq 10 \mathrm{~m}
\end{aligned}
$$$$
\begin{array}{lll}
56 & 58.9 & \text { Ref }
\end{array}
$$$$
\begin{array}{lll}
35 & 74.5 & 2.03
\end{array}
$$$$
\begin{array}{lll}
6 & 46.2 & 0.60
\end{array}
$$

0.94-4.39

0.07

$0.19-1.91$

0.40

266.7 Ref

$\begin{array}{lll}7 & 77.8 & 1.75\end{array}$

0.10-30.82

0.70

$88 \quad 61.5$

$0.07-9.03$

0.86

Distance from farm

$\leq 1 \mathrm{~m}$
$2-10 \mathrm{~m}$
$>10 \mathrm{~m}$

Animals around source

$>10 \mathrm{~m}$
$\leq 10 \mathrm{~m}$

Existence of water source

$\leq 5$ years
$6-10$ years
$>10$ years

Present
Absent

\section{Covered by cement}

Present
Absent

Stagnant water

$$
\text { Present }
$$

Absent

$\begin{array}{llll}77 & 60.2 & \text { Ref } & \\ 20 & 74.1 & 1.89 & 0.75-4.80\end{array}$

1164.7 Ref

$\begin{array}{lllll}14 & 63.6 & 0.95 & 0.25-3.57 & 0.94 \\ 72 & 62.1 & 0.89 & 0.31-2.58 & 0.83\end{array}$

$\begin{array}{lllll}72 & 62.1 & 0.89 & 0.31-2.58 & 0.83\end{array}$

$94 \quad 61.8 \quad$ Ref

$\begin{array}{lll}3 & 100.0 & 0.00\end{array}$

$0.00->1.0 \mathrm{E} 12 \quad 0.24$

$51 \quad 72.9$ Ref

$20 \quad 54.1 \quad 0.44$

$\begin{array}{lll}26 & 54.2 & 0.44\end{array}$

$0.19-1.01$

0.05

0.20-0.96 $\quad 0.04$

$42 \quad 68.9$ Ref

$\begin{array}{lll}55 & 58.5 & 0.64\end{array}$

$0.32-1.26$

$\begin{array}{lll}64 & 58.7 \quad \text { Ref }\end{array}$

$\begin{array}{lll}33 & 71.7 & 1.78\end{array}$

$0.85-3.77$

Enter water with feet

Yes

3968.4 Ref

$\begin{array}{lll}58 & 59.2 & 0.67\end{array}$

$0.33-1.33$

$4 \quad 80.0 \quad$ Ref

\begin{tabular}{|c|c|c|c|c|c|}
\hline No/NA & 93 & 62.0 & 0.41 & $0.04-3.74$ & 0.38 \\
\hline \multicolumn{6}{|l|}{ Cleaning frequency } \\
\hline Never/rarely & 17 & 89.5 & Ref & & \\
\hline Weekly & 46 & 57.5 & 0.16 & $0.03-0.73$ & 0.02 \\
\hline Monthly & 31 & 60.8 & 0.18 & $0.04-0.87$ & 0.03 \\
\hline Yearly & 3 & 60.0 & 0.18 & $0.02-1.78$ & 0.14 \\
\hline \multicolumn{6}{|l|}{$\mathrm{pH}$} \\
\hline 7 & 72 & 57.6 & Ref & & \\
\hline 6 & 25 & 83.3 & 3.68 & $1.32-10.24$ & 0.01 \\
\hline \multicolumn{6}{|l|}{ Turbidity } \\
\hline Cloudy/contain particles & 11 & 78.6 & Ref & & \\
\hline Clear & 86 & 61.0 & 0.43 & $0.11-1.60$ & 0.19 \\
\hline \multicolumn{6}{|l|}{ Odour } \\
\hline Yes & 9 & 90.0 & Ref & & \\
\hline No & 88 & 60.7 & 0.17 & $0.02-1.39$ & 0.06 \\
\hline \multicolumn{6}{|l|}{ Sliminess } \\
\hline Yes & 4 & 40.0 & Ref & & \\
\hline No & 93 & 64.1 & 2.68 & $0.72-9.94$ & 0.12 \\
\hline
\end{tabular}

Table 5 Correlates of enteric pathogenic protozoa in water sources-bivariate analysis (Continued)

$\mathrm{pH}$ of 6 when compared to sources with a $\mathrm{pH}$ of 7 , having water sources with a cloudy turbidity when compared to sources with a clear turbidity, having water sources with an odour when compared to sources with no odour and having slimy water sources when compared to sources that are not slimy (Table 5).

After adjusting for potential confounding by each of the water sources factors that appeared to have an association with prevalence of enteric pathogenic protozoa in the bivariate analysis, only having water sources with a pH of 6 remained a statistically significant predictor of prevalence of enteric pathogenic protozoa in water sources. In fact, the odds of having enteric pathogenic protozoa in water sources with $\mathrm{pH}=7$ was 0.27 times $(95 \% \mathrm{CI}$ : 0.090.83 ) that in water sources with $\mathrm{pH}=6$ (Table 6).

\section{Discussion}

Nowadays, the consumption of water in most developing countries is based on its aesthetic quality with little or no attention paid on its microbiological or chemical quality [20]. It has however been noted that most waterborne infections and deaths in developing countries arise from parasitic diseases. It is thus important to investigate the safety of water used for human consumption [9].

In this study, to appraise the presence of enteric pathogenic protozoa in drinking water sources, we assessed the prevalence of enteric protozoa, characterised the species 
Table 6 Correlates of enteric pathogenic protozoa in water sources-multivariate analysis

\begin{tabular}{|c|c|c|c|}
\hline Predictor & $\mathrm{aOR}^{*}$ & $95 \% \mathrm{Cl}$ & $\overline{p \text {-value }}$ \\
\hline \multicolumn{4}{|l|}{ Location of water source } \\
\hline Open & Ref & & \\
\hline Closed & 1.85 & $0.61-5.55$ & 0.28 \\
\hline \multicolumn{4}{|l|}{ Lid on water source } \\
\hline Yes & Ref & & \\
\hline NA & 1.63 & $0.34-7.73$ & 0.54 \\
\hline \multicolumn{4}{|l|}{ Pipes exposure } \\
\hline Not exposed & Ref & & \\
\hline Exposed & 1.93 & $0.74-5.04$ & 0.17 \\
\hline NA & 0.46 & $0.04-5.72$ & 0.54 \\
\hline \multicolumn{4}{|l|}{ Distance from septic tank } \\
\hline$\leq 10 \mathrm{~m}$ & Ref & & \\
\hline$>10 \mathrm{~m}$ & 0.51 & $0.17-1.53$ & 0.23 \\
\hline \multicolumn{4}{|l|}{ Distance from animals } \\
\hline$\leq 10 \mathrm{~m}$ & Ref & & \\
\hline$>10 m$ & 0.00 & $0.00->1.0 \mathrm{E} 12$ & 0.96 \\
\hline \multicolumn{4}{|l|}{ Existence of water source } \\
\hline$\leq 5$ years & Ref & & \\
\hline 6-10years & 0.55 & $0.15-1.95$ & 0.35 \\
\hline$>10$ years & 0.47 & $0.14-1.64$ & 0.24 \\
\hline \multicolumn{4}{|l|}{ Mud } \\
\hline Absent & Ref & & \\
\hline Present & 1.44 & $0.54-3.87$ & 0.45 \\
\hline \multicolumn{4}{|l|}{ Covered by cement } \\
\hline Absent & Ref & & \\
\hline Present & 0.56 & $0.20-1.58$ & 0.27 \\
\hline \multicolumn{4}{|l|}{ Cleaning frequency } \\
\hline Never/rarely & Ref & & \\
\hline Weekly & 0.15 & $0.02-1.19$ & 0.07 \\
\hline Monthly & 0.20 & $0.03-1.51$ & 0.12 \\
\hline Yearly & 0.19 & $0.01-3.73$ & 0.28 \\
\hline \multicolumn{4}{|l|}{$\mathrm{pH}$} \\
\hline 6 & Ref & & \\
\hline 7 & 0.27 & $0.09-0.83$ & $0.02^{* *}$ \\
\hline \multicolumn{4}{|l|}{ Turbidity } \\
\hline Clear & Ref & & \\
\hline Cloudy/contain particles & 1.98 & $0.40-9.75$ & 0.40 \\
\hline \multicolumn{4}{|l|}{ Odour } \\
\hline No & Ref & & \\
\hline Yes & 4.06 & $0.41-40.54$ & 0.23 \\
\hline
\end{tabular}

Table 6 Correlates of enteric pathogenic protozoa in water sources-multivariate analysis (Continued)

\begin{tabular}{|c|c|c|c|}
\hline \multicolumn{4}{|c|}{ Sliminess } \\
\hline \multicolumn{4}{|c|}{$\begin{array}{l}\text { Sliminess } \\
\text { No }\end{array}$} \\
\hline Yes & 1.59 & $0.10-24.29$ & 0.74 \\
\hline
\end{tabular}

of protozoa found in drinking water sources and also assessed the association between prevalence of protozoa and water sources' characteristics. We document that the prevalence of enteric pathogenic protozoa in water sources is high. Approximately, $63 \%$ of drinking water sources are infested with enteric pathogenic protozoa-too high a percentage per se, to be less concerned about. We also document that eight species of enteric pathogenic protozoa were identified in drinking water sources. These include Cryptosopridium parvum, Cyclospora cayetanensis, Entamoeba histolytica, Giardia lamblia, Sarcocystis spp, Blastocystis hominis, Isospora belli and Balantidium coli. Cryptosporidium parvum was the most predominant enteric parasite identified, spring water was observed to be the most contaminated water source and tap water had all the types of enteric pathogenic protozoa observed. In the study samples, available characteristics of water sources both individually and as a group did not accurately distinguish water sources having enteric protozoa and those that did not. However, water sources with a pH of 6 had statistically significant associations with prevalence of enteric protozoa.

While the prevalence of enteric pathogenic protozoan organisms in drinking water sources in Molyko and Bomaka appears high (62.6\%), it is within the range of prevalence of enteric pathogenic protozoa reported in similar studies done elsewhere. We found no studies on the prevalence and characterisation of enteric pathogenic protozoa in drinking water sources in Cameroon before this study, but the prevalence of enteric protozoa in sub-Saharan Africa has ranged from 36.6 to $77.8 \%$ in Nigeria [13], Zimbabwe [14] and Ghana [10]. The highest prevalence of enteric pathogenic protozoa (77.8\%) we found so far was reported in a study in Ghana [10].

The prevalence of enteric pathogenic protozoa in this study could be influenced by differences in the characteristics of water sources from which samples were collected. The collected water samples for this study may not have been representative of all drinking water sources in the quarters. However, we do not expect the difference in prevalence to be substantial as samples were collected in all quarters of Molyko and Bomaka (the study area). Potential errors due to bias in sample collection or poor sample collection could mean that 
our prevalence of enteric pathogenic protozoa in water sources is over estimated and that our not finding an association between prevalence and many water resources' characteristics is misleading. Nevertheless, the quality of our sample was assured by using one of the investigators to collect water samples for this study in well cleaned containers. Also, the nature of this study's technique did not allow for a quantification of the number of parasites in a unite volume of water-making it difficult to know the possibility of getting infected if one drinks a glass of water for example. However, the results do not only allow a comparison between different water sources but also allows people to choose to avoid one source over another if they cannot sterilise their water.

The identification of protozoa in all water supply sources-borehole $(60.0 \%)$, spring water $(85.7 \%)$, tap water $(64.2 \%)$ and well water $(25.0 \%)$ confirms that no water supply source is safe for drinking no matter how clean or clear its water appears. This reiterates the need to teach community dwellers how to treat water before drinking and the need for water suppliers to revise their water treatment strategies before distributing water for community consumption.

We found no studies done in Cameroon assessing prevalence of enteric pathogenic protozoa in drinking water sources. Most studies conducted were done on stool specimens of patients in hospital [15] and food vendors [16]. While our sample was adequate for estimating the prevalence of enteric pathogenic protozoa in drinking water sources, only a limited number of covariates appeared to have an association with prevalence of enteric protozoa and could be considered as potential predictors. This study showed a significant association between the $\mathrm{pH}$ of the water sources and the presence of enteric pathogenic protozoa. According to WHO guidelines, the normal $\mathrm{pH}$ range for potable water is 6.5-8.5. Enteric pathogenic protozoa were more prevalent in water sources that had $\mathrm{pH}=6$ than those with $\mathrm{pH}=7$ implying that they are found in a slightly acidic milieu than in neutral milieu. This is dissimilar to the results of a study carried out by Tremaine et al. [21], where the prevalence of protozoa was found to be associated to strong acidic or lower $\mathrm{pH}$ media but similar to the study conducted by Johnson et al. [22], which reported that the prevalence of protozoa is related to weak acidic media.

\section{Conclusion}

The prevalence of enteric protozoa in water sources in Molyko and Bomaka is high, spring water is the most contaminated water source and Cryptosporidium parvum is the most common protozoa contaminating water. A water $\mathrm{pH}$ of 6 is associated to the prevalence of protozoa. Community members need to be educated to treat water before drinking to avoid infection by enteric protozoa in water and further studies with larger samples of water need to be conducted to find other correlates of the presence of protozoa in water.

\section{Abbreviations}

aOR: Adjusted odds ratio; CAMWATER: Cameroon Water Utilities Corporation; Cl: Confidence interval; ml: Millilitre; N: Frequency; OR: Odds ratio; Ref: Reference variable; rpm: Rotations per minute; SD: Standard deviation; spp: Species; UNESCO: United Nations Educational, Scientific and Cultural Organisation; USA: United States of America; WHO: World Health

Organisation

\section{Acknowledgements}

We thank the Faculty of Health Sciences administrators for offering us the Teaching Laboratory and necessary equipment for this study. We equally appreciate Mrs Loh Beatrice and Mrs Asanga Joan for providing laboratory equipment and reagents. Finally, we thank Mrs Labah Florence Siri and Fuh Sharon Bih for some financial assistance during the course of this work.

Funding

Study had no funding.

\section{Availability of data and materials}

The authors declare that data and materials shall be available only on request.

\section{Authors' contributions}

FAN and JA conceived and designed the study. FAN, JA and AJCN contributed to study implementation. FAN and PTB conducted laboratory analysis and parasite identification. BAW, JA, FAN and EM conducted data analysis and interpretation of results. BAW, FAN and KKI drafted the manuscript. All authors read, revised and approved the final copy of the manuscript.

\section{Competing interests}

The authors declare that they have no competing interests.

\section{Consent to publish}

Not applicable.

\section{Ethics approval and consent to participate}

Administrative authorisation to collect and analyse water samples for this study was obtained from the regional delegation of public health for the South West Region of Cameroon (Ref: R.11/MINSANTE/SWR/RDPH/PS/411/191).

Received: 21 July 2016 Accepted: 4 November 2016

Published online: 08 November 2016

\section{References}

1. United Nations. The Millennium Development Goals Report [Internet]. 2008 [cited 2013 Dec 4]. Available from: http://mdgs.un.org/unsd/mdg/Resources/ Static/Products/Progress2008/MDG_Report_2008_En.pdf\#page=44

2. Adekunle LV, SRIDHAR M, AJAYI A. An Assesment of the Health and Social Economic Implications of Satchet Water in Ibadan Nigeria: A Public Health Challenge. . 2004;7:5-8.

3. The Facts About The Global Drinking Water Crisis [Internet]. 2010. [cited 2013 Dec 4]. Available from: http://blueplanetnetwork.org/water/facts.

4. Fawell J, Nieuwenhuijsen MJ. Contaminants in drinking water Environmental pollution and health. Br Med Bull. 2003;68(1):199-208.

5. US EPA O. Contaminant Candidate. List 3 - CCL 3 [Internet]. [cited 2016 Nov 5]. Available from: https://www.epa.gov/ccl/contaminant-candidatelist-3-ccl-3

6. Njunda A, Jules CNA, Shey DN, Ngene BA, Kwenti ET. Bacteriological analysis of drinking water in the Cameroon development corporation (CDC) penda-mboko. Afr J Integ Health. 2013;2(1):26-31.

7. Carmena D, Aguinagalde X, Zigorraga C, Fernández-Crespo JC, Ocio JA. Presence of Giardia cysts and Cryptosporidium oocysts in drinking water supplies in northern Spain. J Appl Microbiol. 2007;102(3):619-29. 
8. Egwari L, Aboaba OO. Environmental impact on the bacteriological quality of domestic water supplies in Lagos. Nigeria Rev Saúde Pública. 2002;36(4):513-20.

9. Fletcher SM, Stark D, Harkness J, Ellis J. Enteric protozoa in the developed world: a public health perspective. Clin Microbiol Rev. 2012;25(3):420-49.

10. Kwakye-Nuako G, Borketey P, Mensah-Attipoe I, Asmah R, Ayeh-Kumi P. Sachet drinking water in Accra: the potential threats of transmission of enteric pathogenic protozoan organisms. Ghana Med J. 2007;41(2):62-7.

11. Kang G, Mathew D, Prasana R, Jasper D, Minnie M, Mathan M, Mathan V, Muliyil J. Prevalence of intestinal parasites in rural Southern Indians. Trop Med Int Health. 1998:3(1):70-5.

12. Smith $H$, Lloyd A. Protozoan parasites in drinking water: a UK perspective. New World Water. 1997;1:109-16.

13. Chollom S, Michael UI, Bitrus JG, Michael Al. Parasitological evaluation of domestic water sources in a rural community in Nigeria. Br Microbiol Res J. 2013;3(3):393-9

14. Mtapuri-Zinyowera S, Ruhanya V, Midzi N, Berejena C, Chin'ombe N, Nziramasanga P, Nyandoro G, Mduluza T. Human parasitic protozoa in drinking water sources in rural Zimbabwe and their link to HIV infection. Germs. 2014:4(4):86-91.

15. Mbuh JV, Ntonifor HN, Ojong JT. The incidence, intensity and host morbidity of human parasitic protozoan infections in gastrointestinal disorder outpatients in Buea Sub Division, Cameroon. J Infect Dev Ctries. 2010:4(1):38-43

16. Assob J, Nde P, Nsagha D, Njimoh D, Nfor O, Njunda A, Kamga H. The incidence of feco-oral parasites in street-food vendors in Buea, south-west region Cameroon. Afr Health Sci. 2012;12(3):376-80.

17. Brendan S. Comparison of alternative community water supply technologies in developing countries. Scribd [Internet]. 2009 [cited 2014 Apr 29]; Available from: http://www.scribd.com/doc/132409671/Comparison-ofalternative-community-water-supply-technologies-in-developing-countries

18. Eng J. Sample size estimations: How many individuals should be studied? Radiology. 2003;309-13.

19. World Health Organization. Basic laboratory methods in medical parasitology. MacmillanClays Engl. 1991:11-2:17-20.

20. Addo K, Mensah G, Bokoe M, Bonsu C, Akyeh M. Bacteriological quality of sachet water produced and sold in teshie-nungua suburbs of Accra, Ghana. Afr J Food Agric Nutr Dev. 2009;9(4):1019-30.

21. Tremaine SC, Mills AL. Impact of water column acidification on protozoan bacterivory at the lake sediment-water interface. Appl Environ Microbiol. 1991;57(3):775-84.

22. Johnson DB. Biodiversity and ecology of acidophilic microorganisms. FEMS Microbiol Ecol. 1998;27(4):307-17.

\section{Submit your next manuscript to BioMed Central and we will help you at every step:}

- We accept pre-submission inquiries

- Our selector tool helps you to find the most relevant journal

- We provide round the clock customer support

- Convenient online submission

- Thorough peer review

- Inclusion in PubMed and all major indexing services

- Maximum visibility for your research

Submit your manuscript at www.biomedcentral.com/submit 